\title{
Analytical Approach on Women Education in India
}

\author{
N. Sreedhar ${ }^{1} \&$ B. Ravi Kumar ${ }^{2}$ \\ ${ }^{1}$ Dept. of Economics, Rayalaseema University, Kurnool, A.P. India \\ ${ }^{2}$ Dept. of MBA, Amrita Sai Institute of Science and Technology - India \\ Correspondence: B. Ravi Kumar, Dept. of MBA, Amrita Sai Institute of Science and Technology-India. \\ E-mail:ravi9949418650@yahoo.com
}

Received: May 22, 2018

Accepted: May 30, 2018

Online Published: August 1, 2018

\begin{abstract}
The importance of education had been recognized since the dawn of civilization as the most crucial element of becoming a human being. Women are a very important key factor in the development of human society. In India half of the population consists of women. The 11th five year plan (2007-2012) gave importance to women empowerment in all social, economic and political areas along with continuation of priority keeping over the issues like education, health, and income generating activities. The education and stated that there cannot be educated people without education of women. In India women have a much lower literacy rate than men. Literate women are better decision makers and they contributed more to the life of the community. An African proverb says "If a man is University Education Commission of India (1948-49), just after independence, felt the need of women's e educated, an individual is educated. If a women is educated the entire family is educated". Many states have large rural - urban differential in female literacy rate. Women power is crucial to the economic growth of any country. In recent times, people are realizing the value of women education. Even the low income families are willing to educate their children. Women are very important segment in development at local to global levels. Economic independence and education of women will go a long way in attaining self-reliance for women. The United Nations Development programme constituted eight Millennium Development Goals (MDG) for ensuring equity and peace across the world. The third Millennium Development Goal is directly related to the empowerment of women in India. What Indian women need therefore is not just empowerment, but a complete "Identity Revolution".
\end{abstract}

Keywords: Literacy Rate, India, Education, Women.

\section{Introduction}

The importance of education had been recognized since the dawn of civilization as the most crucial element of becoming a human being. Women are a very important key factor in the development of human society. In India half of the population consist of women resources. They have been identified as key agents of sustainable development and women's equality is regarded as central to a more holistic approach towards establishing new patterns and processes of development. The contribution of women and their role in the family as well as in the economic development and social transformation are important. Their work participation is less when compared to men. Women empowerment has emerged as an important issue in India of late. The importance of women development has been noticed by the Government of India from the day of the implementation of first five year plan (1951-56). The second five year plan (1956-61) continued to reflect the welfare concept besides giving importance and priority to women's education. The 11th five year plan (2007-2012) gave importance to women empowerment in all social, economic and political areas along with continuation of priority keeping over the issues like education, health, and income generating activities. 
Education is the most powerful and effective instrument for men and women. Education not only helps in acquisition of knowledge and the required skills but also enlightens one about different occupational opportunities and mobility. Generally, a high and increasing education level gives exposure to the outer world. It empowers women and gives them the opportunity to earn their livelihood and make them independent economically, politically, and socially. The importance of education for women, therefore, is even more crucial since they have to battle discrimination from birth to death and are in a constant struggle to realize their human rights. Women are the most vulnerable human beings on earth and in order to redeem their humanity it is necessary to create possibilities by which they can access the agency of education and literacy.

The movement for improving women's status all over the world has always emphasized education as the most significant instrument for changing women's subjugated position in the society. The University Education Commission of India (1948-49, just after independence, felt the need of women's education and stated that there cannot be educated people without getting women educated. While discussing the importance of education to uplift the status of women, Chatterji (1993) points out that "education helps in raising the status of women in four ways. Education helps women to (1) earn an income in later life, (2) participate actively in public life, (3) determine her own fertility and (4) achieve personal autonomy. All these four facets can be understood easily by juxtaposing the merits of an educated woman against the demerits of uneducated one."

2. Theoretical analysis of women Education

In India women have a much lower literacy rate than men. A long string of educational programmes have been started by the Government and they have produced some results so that Indian women today have a literacy rate of more than 65 percent as per the Census of 2011, and it was 8.9 percent in 1951. But our women are still far behind men who have a literacy rate of 82 percent in 2011, and it was 27 percent in 1951. The latest census has recorded that the increase in female literacy has been sharper than the increase in male literacy in the past decade. This is very heartening news because it reflects that the Government is showing results as far as educational programmes for women are concerned.

Table 1. Literacy Rate in India

\begin{tabular}{llll}
\hline Year & Persons & Males & Females \\
\hline 1951 & 18.3 & 27.2 & 8.09 \\
\hline 1961 & 28.03 & 40.04 & 15.03 \\
\hline 1971 & 34.05 & 46.00 & 22.00 \\
\hline 1981 & 41.04 & 53.04 & 28.05 \\
\hline 1991 & 52.02 & 64.01 & 39.03 \\
\hline 2001 & 65.04 & 75.08 & 52.01 \\
\hline 2011 & 74.04 & 82.14 & 65.46 \\
\hline
\end{tabular}

Source: Census of India, $2001 \& 2011$.

Women's education is linked to a significant improvement in the literacy and educational levels of their children and better health and nutrition standards in the family, literate women are better decision makers and they contribute more to the life of the community. Educated women are less prone to be subjected to domestic violence and other forms of exploitation. Crimes against women are reported more in urban areas and less in rural areas because illiterate women are less likely to speak out against violence and even less likely to approach a police station for help.

In India there has been some catching up in literacy rates for both men and women between rural and urban areas, the gender gaps continue to be unacceptably large especially for females. As per 2001 Census 46.70 percent women in rural areas were literate as opposed to nearly 73.20 percent women in urban areas, as per 2011 Census 58.8 percent of women in rural areas were literate as opposed to nearly 79.9 percent women in urban areas. Though there have been substantial increases in literacy rates in both urban and rural areas, the gap between the two sectors has not been narrowed appreciably. Many states have large rural-urban differentials in female literacy.

3. Education and Empowerment

An African proverb says "If a man is educated, an individual is educated; if a women is educated the entire family is educated". Education can be an effective tool for women's empowerment. It is both an indicator and an instrument of development. The human capital theory stipulates that education is an investment that yields returns for the individual and society at large. To get the full benefit of education it should be provided equally to both men 
and women. In India female literacy rate is as low as 65.46 percent as compared to 82.14 percent of men. Education will work as a catalyst towards empowering women in India.

Mahila Samakhya is a women's movement, which has transformed the lives of women in 14000 Villages in 60 districts of nine states of India viz. Karnataka, Gujarat, Andhra Pradesh, Kerala, Bihar, Assam, Jharkhand, U.P. and Uttaranchal, started as an awareness programme by the Ministry of HRD in pursuance of the National Policy of Education -1986 as updated in 1992, today it has entered the areas of education, health, human rights and governance with the objective of creating a gender-just society.

Education will be used as an agent of basic change in the status of women. In order to neutralize the accumulated distortions of the past, there will be a well-conceived edge in favour of women. The national system will play a positive interventionist role in the empowerment of women and it will develop new values through re-designed curricula, text-book, the training and orientation of teachers, decision-makers and administrators, the active involvement of educational institutions. Women studies will be promoted as a part of various courses and educational institutions encouraged to take-up active programmes to further women's development. Literacy and education are the most essential inputs for empowerment of women. A critical analysis of the five year plans over the years starting from independence reflects that in the earlier phase of developmental planning, the concept of women development was mainly "welfare" oriented. During seventies there was a shift from welfare to development, which started recognizing women as participants of development. The eighties adopted a multidisciplinary approach with a special thrust on health, education and employment and number of programmes were launched to make women independent.

\section{Women Empowerment and Employment}

The present century has witnessed an emergence of educated and trained women in white collared jobs as teachers, engineers, lawyers, doctors, corporate executives, and the like in India's growing economy. But the real problem is that of unskilled and illiterate women who have to seek whole time unskilled jobs. Therefore there is a need for them to improve their skills and qualify themselves for semi skilled and skilled jobs. Towards this end educational programmes have to be restructured aiming to equip them with necessary skills required in modern upcoming trades. The position and status of women also varies from urban to rural areas, the educated to the uneducated, the employed to unemployed, the upper strata to the lower economic strata and also from job to job. The educated women are more productive both at home and in the work place.

\section{Women Empowerment in India}

The Year 2001 was declared by the Government of India as "Women's Empowerment Year" to focus on a vision where women are equal partners like men, because the constitution of India grants equality to women in various fields of life. In the past, the position of women was miserable in the society and even women were not ready to undertake any assignment or job due to many reasons like fear, male dominance in the society and purda system but time has been changed now. Women of today are not like the early days. Now, they are always ready to come forward and want more economic independence, identity, achievements, equal status in the society and greater freedom. The Government of India provides for Self- Help Groups (SHG) to them so that proper attention should be given to their economic independence through self employment, entrepreneurial development.

The Self-Help Groups have been emerged as a powerful instrument in order to alleviate poverty and for the empowerment of women in the rural economy. In this way, Self-Help Groups are important not only to reduce rural poverty, to promote rural savings but also to increase gainful employment. Empowerment of women in India has focused on three important aspects, viz. economic empowerment, integrated development, and consciousness rising. 6. New Opportunities

But in general the radical changes taking place in many countries open new opportunities for polices on women. On the one hand, this is because the extent of the disadvantaging and suppression of women is more visible. In some countries, women have been able to push through binding legal regulations (election laws, political party statutes women's quota rules for local councils), in order to guarantee their stronger participation in parties and trade unions. With the programme slogans of "empowerment" and redistribution of power, women who are organized self-help organization, associations, networks and political parties are demanding participation in political decision processes and access to the political institutions. They are striving for social power in a bid to influence the factors which cause discrimination against them.

The transitions from authoritarian to democratic forms of government in a great number of countries have placed women's organizations in a changed environment. There are now countless such bodies and their combined clout is changing the status of women and helping to broaden their scope for social action. But in some countries women are still faced with considerable difficulties in organizing themselves with formal status.

On account of progressive impoverishment, however, the women's newly-won scope for action and shaping their lives is markedly cramped. Current developments such as religious fundamentalism or economic recession have 
inhibiting impacts on new approached to policies on women in part, one must speak of a "backlash". Even where the legal position of women have been improved they have not been able to assert their social, economic and political rights. In some countries, it's feared that only elitist women's organizations will have a chance to break into the political process.

7. Conclusion

Women power is crucial to the economic growth of any country. In India this is yet to meet the goal despite reforms. Little has been achieved in the area of women education, but for this to happen, this sector must introduce a chain of reforms. Though India could become one of the largest economies in the world, it is being hindered due to a lack of women's participation. Education is universally accepted as a fundamental agent of socio-economic upliftment, but women have not been fairly treated as for the access to education is concerned.

In recent times, people are realizing the value of women education. Even the low income families are willing to educate their children. Women are very important segment in development at all levels from local to global. Economic independence and education of women will go a long way in attaining self-reliance for women. Real change will come when women are treated on par with men and given equal opportunities. When that happens, India will be able to harness its women power and emerge as a respected nation. Women in India now participate in all activities such as education, sports, politics, media, art and culture, service sector, science and technology, etc., Indira Gandhi who served as Prime Minister of India for an aggregate period of fifteen years is the world's longest serving women Prime Minister.

Conferences and discussions about women issues are welcome step but what need to be tackled are the basic perceptions of the society that gives rise to the aberrations. Today in all sectors of the economy women concerns have been flagged. But the change lies in converting these into reality, as rightly observed by Nehru, "The status of women reflects the character of the country". So, we have to look into the gender issues with more sensitivity in the New Millennium. The United Nations Development programme constituted eight Millennium Development Goals (MDG) for ensuring equity and peace across the world. The third Millennium Development Goal (MDG) is directly related to the empowerment of women in India. What Indian women need therefore is not just empowerment, but a complete "Identity Revolution".

References

Rajesh pal. (2011).Women Empowerment through Formative Education. 'Social Welfare' 58(6), 11-12 Anupam Hazra, .(2011).Women Need an Identity Revolution" 'Social Welfare' 57(12),.8-10

V.Govindappa \&D.Hanumantha Rayadu,"Economic Empowerment of Women- A case study of garment factory workers in Doddaballapur Industrial Area".'Southern Economist' 50(19),44-46

A. Celine Rita and D.Rajasekhar.(2012). Role of Women in Independent India. 'Southern Economist' 51(11),7-,9

R.Vidhya .(2012). Status and Empowerment of Women in India.Southern Economist,50(20),8-10

N.S. Sumathi .(2014).Self Help Groups: An effective approach to women empowerment in India". 'International Journal of Applied Management Research,6,67

Census of India 2001

Shilpa Tripathi .(2010).Redressing Illiteracy: Quiet Revolution for the Empowerment of Women" 'Social Welfare' $57(4)$

Copyrights

Copyright for this article is retained by the author(s), with first publication rights granted to the journal.

This is an open-access article distributed under the terms and conditions of the Creative Commons Attribution license (http://creativecommons.org/licenses/by/4.0/) 